\title{
The Process of Immobilization of ZnO Nanorods Surface with Galactose Oxidase
}

\author{
La Phan Phương Ha, Ngo Van Chi Quang and Tran Quang Trung \\ University of Natural Science, Vietnam National University, Ho Chi Minh City 748000, Vietnam
}

\begin{abstract}
ZnO}$ nanorods, with the c-axis orientation used for transparent conductors, solar cells, sensors..., especially the functionalized $\mathrm{ZnO}$ nanorods with some kinds of enzymes have been used for biosensor. In this work, we describe the process immobilization of galactose oxidase on $\mathrm{ZnO}$ nanorods surface with glutaraldehyde as a cross-linker molecule to make the working electrode in electrochemical biosensor. ZnO nanorods were grown on FTO (Fluorine-doped tin oxide) substrate by solution method at low temperature. The crystalline phase and orientation of $\mathrm{ZnO}$ nanorods were identified using $\mathrm{X}$-ray diffraction. The efficiency of the immobilization was calculated by Braford method showed that about $36 \%$ enzyme content was immobilized on ZnO nanorods surface. The working electrode based on the immobilized $\mathrm{ZnO}$ nanorods was tested in galactose solution by CV (cyclic voltammetry) method indicated the value of current intensity is about $0.14 \mu \mathrm{A}$. These results clearly demonstrate the potential of galactose sensor based on $\mathrm{ZnO}$ nanorod.
\end{abstract}

Key words: $\mathrm{ZnO}$, solution method, Braford method, galactose oxidase, galactose biosensor.

\section{Introduction}

For many applications of nanorods, such as field emission and polymer-inorganic solar cell, catalyst, gas/bio sensor, their 1D structures play an important role $[1,2] . \mathrm{ZnO}$ nanorods have some advantages such as nontoxic, fast electron transfer, high surface to volume, low cost and it has high ionic bonding characteristic, so it is stabile for a long time at biological pH. Furthermore, the IEP (isoelectric point) of $\mathrm{ZnO}$ is high (about 9.5) and thus it is a better material to immobilize low IEP such as enzyme or protein. With these characteristic, $\mathrm{ZnO}$ nanorods structure is applied in biosensor. In this report, we present the solution method to grow $\mathrm{ZnO}$ nanorod and the immobilization process of galactose oxidase enzyme on $\mathrm{ZnO}$ nanorods surface. The solution method is used to grow $\mathrm{ZnO}$ nanorods because of some advantages as simple method, reaction to form rods is occurred at low temperature (about $50{ }^{\circ} \mathrm{C}-120{ }^{\circ} \mathrm{C}$ ). Our experiment results show that $\mathrm{ZnO}$ nanorods have about

Corresponding author: La Phan Phuong Ha, MSc, research fields: nanomaterials for gas sensor and biosensor.
$40 \mathrm{~nm}-50 \mathrm{~nm}$ diameter, they aligned vertically on $\mathrm{ZnO}$ seed coated FTO substrate and have a preferential orientation of (002) plane. Galactose oxidase enzyme $(2 \mathrm{mg} / \mathrm{mL}$ concentration) was immobilized on $\mathrm{ZnO}$ nanorod surface with different time immobilization, the efficiency of this process was about $36.5 \%$ with $3 \mathrm{~h}$ immobilization time.

\section{Experimental}

\subsection{The Growth of ZnO Nanorods}

The seed $\mathrm{ZnO}$ is important in growth process of $\mathrm{ZnO}$ nanorods by solution method because this method is simple, low-cost, can be synthesized at low temperature $\left(50{ }^{\circ} \mathrm{C}-120{ }^{\circ} \mathrm{C}\right)$ to grow $1 \mathrm{D}$ structured $\mathrm{ZnO}$ nanomaterial [3]. $\mathrm{RG}$ (reagent grade) zinc acetate dehydrate $\left(\mathrm{Zn}\left(\mathrm{CH}_{3} \mathrm{COO}\right)_{2} \cdot 2 \mathrm{H}_{2} \mathrm{O}\right)$ and MEA (monoethanolamine) were first dissolved in an ethanol solvent with $\mathrm{Zn}^{2+}$ concentration of $0.75 \mathrm{M}$ to form sol solution. This solution was magnetic stirred in $2 \mathrm{~h}$ at room temperature. After that, FTO substrate was coated from sol solution by spin coating and then the annealling process was performanced at $500{ }^{\circ} \mathrm{C}$ to form 
$\mathrm{ZnO}$ crystal. At the end, this product was cool down at room temperature to have $\mathrm{ZnO}$ seed layer.

$\mathrm{ZnO}$ nanorods to grow by solution method from seed ZnO coated FTO substrate. Precursor zinc nitrate dehydrate $\left(\mathrm{Zn}\left(\mathrm{NO}_{3}\right)_{2} \cdot 2 \mathrm{H}_{2} \mathrm{O}\right) \quad$ and hexamethylenetetramine (HMTA, $\mathrm{C}_{6} \mathrm{H}_{12} \mathrm{~N}_{4}$ ) were first dissolved in an aqueous solvent with $\mathrm{Zn}^{2+}$ concentration $0.02 \mathrm{M}$. This solution was magnetic stirred in $2 \mathrm{~h}$ at room temperature. After that, substrate coating $\mathrm{ZnO}$ seed was dipped in that solution and kept at $5 \mathrm{~h}, 80{ }^{\circ} \mathrm{C}$ to growth $\mathrm{ZnO}$ nanorods following some below chemical reaction. Then, obtained products were cool down at room temperature.

\subsection{The Immobilization of Galactose Oxidase Enzyme on ZnO Nanorods Surface}

In this part of the experiment work, we prepared two kinds of solution: $2.5 \%$ GA (Glutaraldehyde) in 0.1 $\mathrm{mM}$ PBS (phosphate buffer solution) as well as galactose oxidase solution in PBS having a concentration of $2 \mathrm{mg} / \mathrm{mL}$ of enzyme. These GA and enzyme solutions are mixed in one bottle, then $\mathrm{ZnO}$ nanorods substrate is dipped into it for different times in order to investigate the saturation of the $\mathrm{ZnO}$ nanorods surface with the enzyme. The efficiency of this immobilization was calculated by Braford method based on the enzyme content adhered to $\mathrm{ZnO}$ nanorods surface. With Braford method, to define the enzyme content immobilized on $\mathrm{ZnO}$, we measure OD (optical

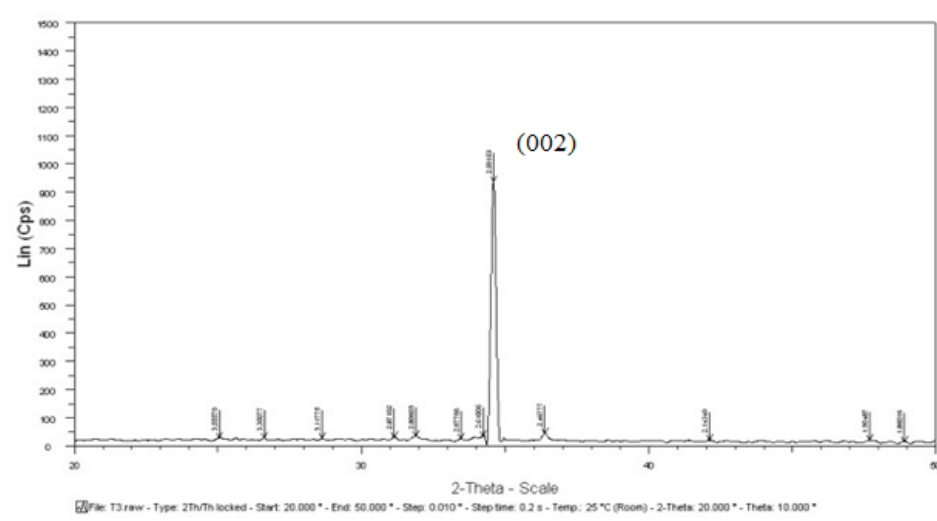

(a) density) of enzyme solution at $559 \mathrm{~nm}$.

The $200 \mathrm{mM}$ concentration galactose solutions were prepared to test the activity of the enzyme immobilized $\mathrm{ZnO}$ nanorods. The electrochemistry response of the proposed biosenor based on the immobilized $\mathrm{ZnO}$ nanorods in galactose solution was measured by $\mathrm{CV}$ (cyclic voltammetry) method with MPG-2 analyer which used the immobilized $\mathrm{ZnO}$ nanorods as a working electrode and $\mathrm{Ag} / \mathrm{AgCl}$ as a reference electrode.

\section{Results and Discussion}

\subsection{The Growth of ZnO Nanorods by Solution Method}

Fig. 1a shows the $\mathrm{X}$-ray diffraction pattern of $\mathrm{ZnO}$ nanorods that grew on seed $\mathrm{ZnO}$ coated substrate showed the significantly higher intensity from the (002) peak, indicated that the nanorods were preferentially orientated along c axis direction. This obtained result was confirmed that the seed layer $\mathrm{ZnO}$ has an important role in alignment growth of $\mathrm{ZnO}$ nanorods on $\mathrm{ZnO}$ seed layer having $\mathrm{c}$ axis orientation. The SEM images of these samples are observed (Fig. 1b) the hexagonal structure of $\mathrm{ZnO}$ nanorods with the higher vertical alignment on $\mathrm{ZnO}$ seed coated substrate. The average diameter of nanorods in this situation was 40 nm.

These results show that we successfully grow $\mathrm{ZnO}$ nanorods with good orientation, high surface area. This structure can be used to immobilize enzyme on it.

Fig. 1 (a) XRD of ZnO nanorods, (b) SEM of ZnO nanorods.

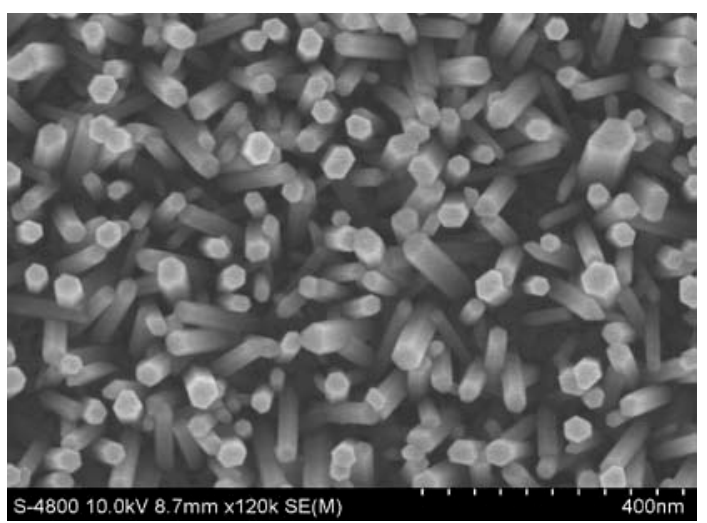

(b) 
3.2 The Immobilization of Galactose Oxidase Enzyme on Zno Nanorods Surface

We immobilized galactose oxidase enzyme on $\mathrm{ZnO}$ nanorods in $1 \mathrm{~h}, 2 \mathrm{~h}, 3 \mathrm{~h}, 4 \mathrm{~h}$ time. The enzyme content immobilized on $\mathrm{ZnO}$ will be calculated by Braford method. This method relies on the change of maximum absorption wavelength of Coomassie Brillant Blue reagent when the reagent combines with albumin enzyme. Without albumin enzyme, the maximum absorption wavelength of the reagent in solution is 465 $\mathrm{nm}$. However when we add albumin enzyme to this solution, the maximum absorption wavelength changes to $595 \mathrm{~nm}$. The OD (optical density) of enzyme solution was measured by Spectrophotometer at $595 \mathrm{~nm}$ wavelength and this OD value relates to enzyme content in solution. With Braford method, scientists set up the standard curve to calculate enzyme content as in Fig. 2. In this report, the albumin enzyme was replaced with galactose oxidase. The galactose oxidase content immobilized on $\mathrm{ZnO}$ was calculated from the OD value of galactose oxidase enzyme solutions after the immobilization, and the efficiency of the immobilization $(\mathrm{H} \%)$ can be found out based on standard curve of Braford method. The result of OD measurement with different immobilization time is shown in Table 1.

$$
H \%=\frac{\text { beginning enzyme content }- \text { enzyme content after the immobilization }}{\text { beginning enzyme content }} \cdot 100 \%
$$

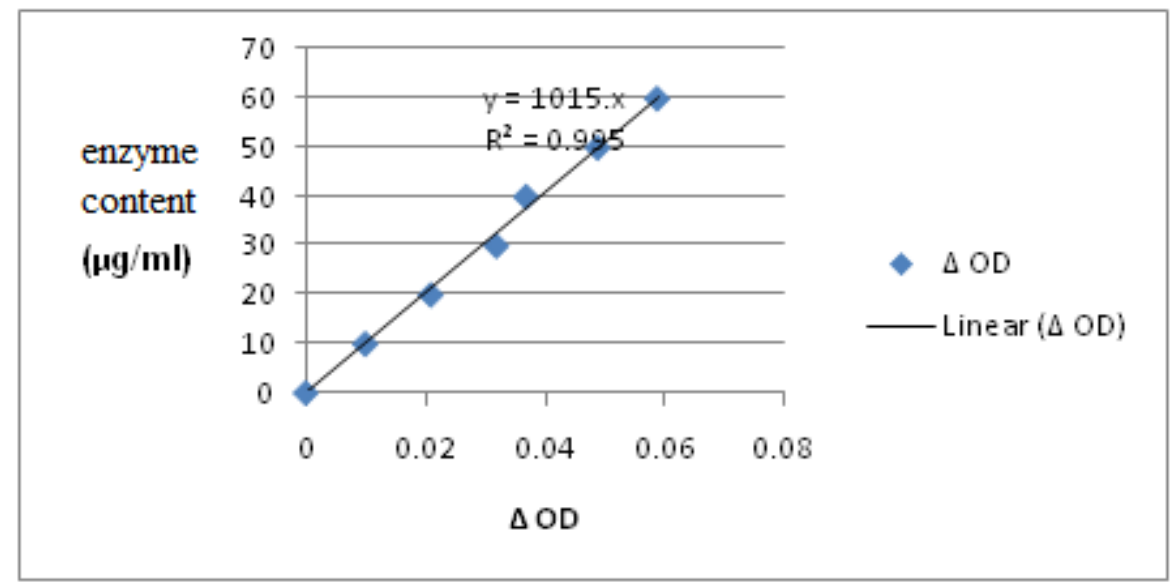

Fig. 2 The standard chart of Braford method.

Table 1 OD value and the efficiency of the immobilization with different immobilization time.

\begin{tabular}{lllll}
\hline Immobilization time & $1 \mathrm{~h}$ & $2 \mathrm{~h}$ & $3 \mathrm{~h}$ & $4 \mathrm{~h}$ \\
\hline OD value & 0.095 & 0.091 & 0.086 & 0.088 \\
$\Delta$ OD & 0.034 & 0.03 & 0.025 & 0.027 \\
Enzyme concentration (find out from Braford standard graph) $(\mu \mathrm{g})$ & 34.5 & 30.45 & 25.38 & 27.5 \\
Enzyme content after the immobilization $(\mu \mathrm{g})$ & $1,725.5$ & $1,522.5$ & 1,269 & 1,440 \\
Immobilized enzyme content $(\mu \mathrm{g})$ & 274.5 & 477.5 & 731 & 560 \\
$\mathrm{H} \%$ & 13.8 & 24 & 36.5 & 28 \\
\hline
\end{tabular}


In Table 1, the efficiency of the immobilization is $13.8 \%, 24 \%$, 36.5\% and 28\% corresponding to $1 \mathrm{~h}, 2 \mathrm{~h}$, 3 h, 4 h immobilization time, and it shows that we successfully immobilized galactose oxidase on $\mathrm{ZnO}$ nanorods with the efficiency of the immobilization is $36.5 \%$ corresponding to $3 \mathrm{~h}$ immobilization time.

\subsection{The Activity of the Immobilized $\mathrm{ZnO}$ Nanorods}

To test the activity of the enzyme immobilized $\mathrm{ZnO}$ nanorods with $3 \mathrm{~h}$ immobilization time, we compared the activity of the enzyme immobilized $\mathrm{ZnO}$ nanorods to pure ZnO nanorods on FTO substrate in $200 \mathrm{mM}$ concentration galactose solution. In this solution, the $\mathrm{CV}$ curve of pure $\mathrm{ZnO}$ nanorods electrode showed that the value of current intensity is about $0.011 \mu \mathrm{A}$. On the other hand, with the immobilized $\mathrm{ZnO}$ nanorods electrode, this value increases to $0.14 \mu \mathrm{A}$ (Fig. 3).
This result indicated that the immobilized $\mathrm{ZnO}$ nanorods electrode reacted with galactose in galactose solution to change the value of current intensity. This change can be explained base on the oxidation of galactose in the presence of immobilized galactose oxidase, galactohexodialdose and $\mathrm{H}_{2} \mathrm{O}_{2}$ were produced into the solution and these products created a potential change at the electrode, as given in the following equation $[4,5]$ :

\section{Galactose oxidase}

Galactose $+\mathrm{O}_{2} \longrightarrow$ Galacto-hexodialdose $+\mathrm{H}_{2} \mathrm{O}_{2}$ $\mathrm{H}_{2} \mathrm{O}_{2}$

$$
\longrightarrow \mathrm{O}_{2}+2 \mathrm{e}^{-}+2 \mathrm{H}^{+}
$$

With these achieved results above, it shows that we successfully immobilized galactose oxidase on $\mathrm{ZnO}$ nanorods and this immobilized $\mathrm{ZnO}$ nanorods electrode has good operation ability in galactose solution.

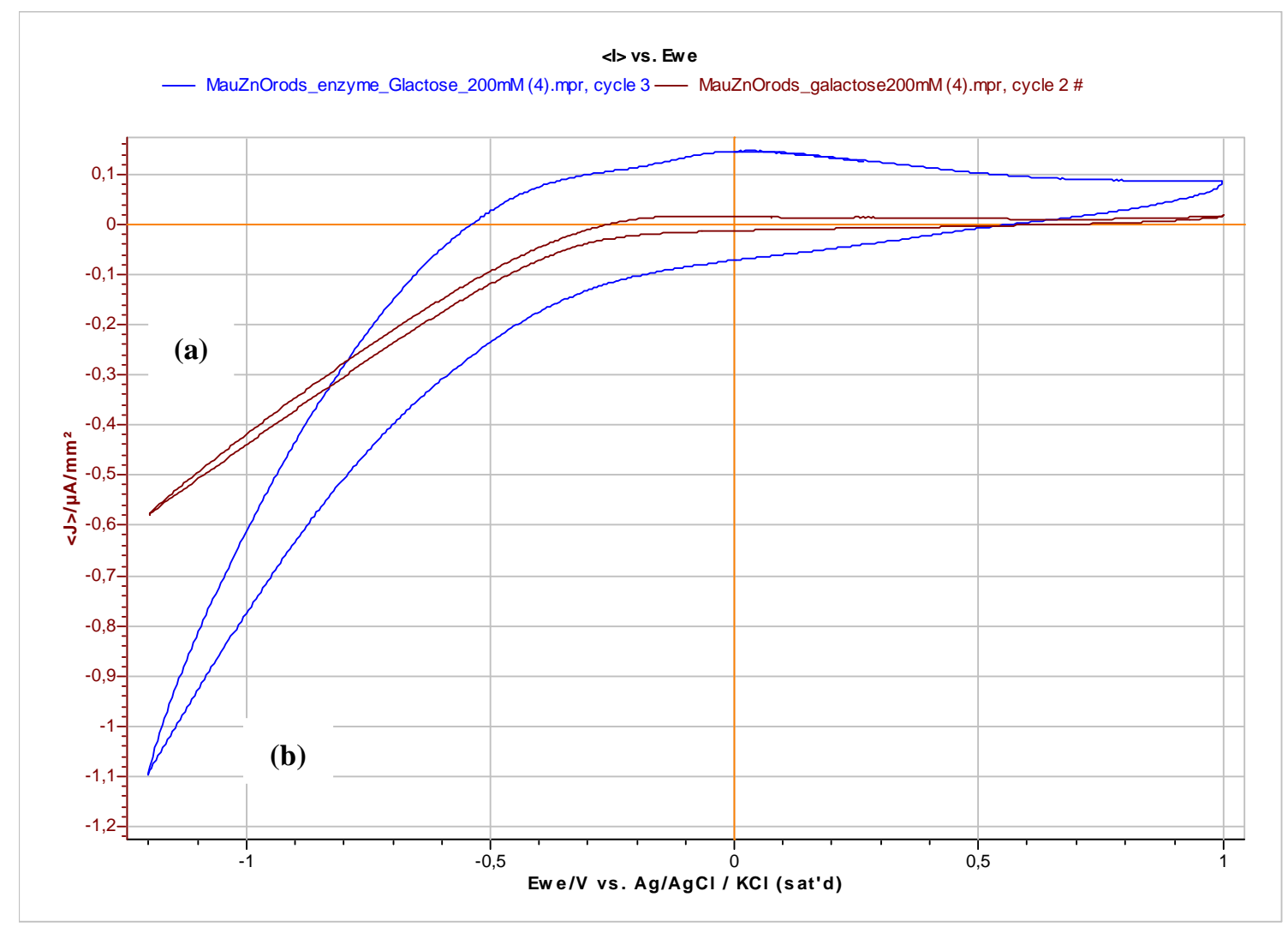

Fig. 3 The $\mathrm{CV}$ curve of (a) the pure $\mathrm{ZnO}$ nanorods and (b) the immobilized $\mathrm{ZnO}$ nanorods in $200 \mathrm{mM}$ galactose solution. 


\section{Conclusions}

We have successfully grown up the $\mathrm{ZnO}$ nanorods on seed $\mathrm{ZnO}$ coated FTO substrate by solution method, the nanorods were preferentially orientated along c axis direction, the average diameter of nanorods in this situation was 40-50 $\mathrm{nm}$. We also successfully immobilized galactose oxidase on $\mathrm{ZnO}$ nanorods with the efficiency of the immobilization is $36.5 \%$ corresponding to $3 \mathrm{~h}$ immobilization time. These results are basic for galactose sensor application based on $\mathrm{ZnO}$ nanorods in the next step to test some parameters influenced the working of sensor, such as the $\mathrm{pH}$, the temperature, the concentration $\ldots$ of galactose solution.

\section{Acknowledgement}

We thank for Solid State Physic Department, University of Natural Sciences, VNU-HCM.

\section{References}

[1] Sung, Y. M., Noh, K. M., Woo, C. K., and Kim, T. G. 2012. "Enhanced Glucose Detection Using Enzyme-Immobilized Zno/Zns Core/Sheath Nanowires.” Sensors and Actuators B 161: 453-9.

[2] Lee, K. H., Kwon, H. Y., and Kim, T. W. 2008. "Microstructural and Optical Properties of Zno Nanowires Synthesized on Si Substrates without a Catalyst.” Physica E 41 (7): 189-92.

[3] Hu, X. L., Masuda, Y., Tatsuki, O., and Kazumi, K. "Low-temperature Fabrication of $\mathrm{ZnO}$ Nanoarray Films by Forced Hydrolysis of Anhydrous Zinc Acetate Layer." Journal of Crystal Growth 311: 597-600.

[4] Khun, K., Ibupoto, Z. H., Nur, O., and Willander, M. 2012. "Development of Galactose Biosensor Based on Functionalized ZnO Nanorods with Galactose Oxidase.” Journal of Sensor.

[5] Sharma, S. K., Suman, C. S., Pundir, N., and Sehgal, A. K. 2006. "Galactose Sensor Based on Galactose Oxidase Immobilized in Polyvinyl Formal.” Sensor and Actuators B 119 (1): 15-19. 